\title{
Burden of Undiagnosed Hypertension Among Adults in Urban Communities of Southwest Ethiopia [Corrigendum]
}

\author{
Mogas SB, Tesfaye T, Zewde B, et al. Integr Blood Press \\ The authors apologize for this error.
}

Control. 2020;13:69-76.

The authors have advised there is an error in the author list on page 69. The author name "Belay Zewde" should read

"Belay Zawdie".

\section{Publish your work in this journal}

Integrated Blood Pressure Control is an international, peer-reviewed open-access journal focusing on the integrated approach to managing hypertension and risk reduction. Treating the patient and comorbidities together with diet and lifestyle modification and optimizing healthcare resources through a multidisciplinary team approach constitute key features of the journal. This journal is indexed on
American Chemical Society's Chemical Abstracts Service (CAS). The manuscript management system is completely online and includes a very quick and fair peer-review system, which is all easy to use. Visit http://www.dovepress.com/testimonials.php to read real quotes from published authors. 